\title{
Identity Negotiation through Positioning in Two Selected Short Stories from Darraj's The Inheritance of Exile
}

\author{
Dalia Hamid ${ }^{*}$
}

\section{Introduction}

Identity is defined as people's sense of who they are as its main concern is to answer the simple question of who we are (Djité 2006; Huntington 2004). A broader definition considers identity to be the discourse construction of membership in a group (Kroskrity 1999). For example, an individual may use discourse signifying a certain group in order to mirror his/her relatedness to that group. This process of self-identification helps people to define the entities they are associated with (Castells 2001). One's identity is subject to change as discourse proceeds because it is created by the individual and by others during a specific situation (Smith 1992).

Discourse is considered to be a way of world representation (Fairclough 2003). Discourse analysis' main interest is examining patterns of language, or discourses, in relation to the social and the cultural contexts of these discourses (Paltridge 2006). Critical Discourse Analysis (CDA) tackles discourse, whether oral or written, as a form of social practice (Fairclough and Wodak 1997; Wodak 1995, 1996). Social practices are sets of rules which are formed over long periods of time to govern the way people act and react in a social event (Fairclough 2003). Accordingly, one's actions and reactions are tied to the timing of the event, the location, the agents involved, their positions, the situational context and the sets of beliefs pertaining to the agents. In other words, one's practices rely on his identity and this identity is represented by one's discourse.

Discourse about identity has to do with the persona that a particular person claims in talking. It refers to roles, rights and power enacted through language (Scollon 1996). Positioning is the act of allocating roles/positions to speakers "in the discursive construction of personal stories" (Langenhove and Harré 1999, 17). It is the discursive process by which "selves are located in conversation" through the storyline that is achieved by participants (Davis and Harré, 1990,

* Lecturer in Linguistics, Department of Foreign Languages (English), Faculty of Education, Tanta University, Egypt.

Cairo Studies in English - 2020(2): https://cse.journals.ekb.eg/ 
48). The theory of positioning deals with the manner in which people use language so as to locate themselves and others throughout conversations/talks (Moghaddam and Harré 2010). Fairclough (1992) explains that language has an effect on endowing speakers and addressees with certain positions. Interactive positioning has to do with the effect of a person's words on the position of another; reflexive positioning refers to cases "in which one positions oneself" (48).

Susan Muaddi Darraj is a daughter of immigrant Palestinian parents. Darraj's The Inheritance of Exile (2007) is a collection of separate short stories about four Arab - American women in Philadelphia: Nadia, Aliyah, Hanan and Reema. Darraj, an Arab American, also narrates the stories of their mothers, who are Palestinian immigrants. Consequently, Darraj's short narrative contains eight stories. Two stories, that of Nadia and her mother Siham, are selected for this study. The four women live among ethnic groups -Italians and Irish-and always try to make peace between their Arab identity and their American one. The cultural gap between Palestine and The United States makes the women compare the two realities: the past in Palestine and the present in America. Reality is a social construction that is created, enhanced, switched or damaged through interaction (Gordon and Pellegrin as cited in James 2014). This struggle between the two realities/ lives is negotiated and expressed in discourse. Hence, this research attempts an in-depth investigation of identities expressed through discourse: the woman's cultural heritage as a Palestinian-Arab and her identity as an American citizen.

Narration of events and experiences is a way of learning about the roles played by interlocutors and the relevant rights/duties. Narrating in itself is a practice of giving meaning to interpret past episodes and anticipate future happenings (Barkhuizen, Benson and Chik 2014; Brockmeier 2012). Positioning Theory (PT), rooted in cultural psychology and feminism, is about discourse exchanged at the present moment (Aydar 2019) and the obligations assumed among participants as the narration proceeds (Davies and Harré 1990, 1999; Harré 2012). This research is about the link between PT, as a theoretical framework, and negotiated identities in narrative discourse. PT investigates conversational interactions in an attempt to uncover the role-based identities among characters and the way they perceive themselves.

\section{Aim and Significance}

This research aims to explore the linguistic construction of positioningnegotiated identities in two selected short stories from Susan Muaddi Darraj's 
The Inheritance of Exile (2007). Guided by positioning analytical framework proposed by Langenhove and Harré (1999) and Davies and Harré (1990), this research seeks to examine Nadia's and Siham's identities, as being examples of Arab Americans who experience double lives. This examination is significant in the sense that it sheds light on Nadia and Siham's fight, which is exposed by discourse, for making harmony between two completely different worlds: the Arab and the American. It also uncovers the way Nadia and Siham struggle to harmonize their Palestinian root/identity with their present American identity. Thus, this study aims at answering the following questions: What does positioning analysis tell about Nadia and Siham's identities and inner conflicts? What are the positions Nadia takes on? How is she positioned by others? What are the identities uncovered by Nadia's positioning of her own self and others? How is Siham positioned throughout the storylines? What are the identities negotiated by Siham's discourses?

\section{Theoretical Framework}

Positioning as a concept has been introduced by Smith (1988) in his differentiation between a person as an agent and the subject. While the former refers to the doer of the action, the latter has to do with the subject-position rendered by discourse (Davies and Harré 1990). Positioning varies according to the circumstances and social contexts people are part of (Davies 1989). In consequence, the subject may have more than one position according to the storyline he/she is involved in. Accordingly, "the discursive production of a diversity of selves" is worthy of attention and examination (Davies 1989, 47). This is a preliminary step towards the detection of identity construction in interactions.

According to Langenhove and Harré (1999), the concepts of "positions/positioning" are introduced by Holloway (1984) when she discusses positions and gender differentiations in discourse. Rom Harré further develops the theory (2012) and expands it in collaboration with his fellows (e.g., Davies and Harré 1990, 1999; Harré and Langenhove 1991; Langenhove and Harré 1999). Positioning is the construction of "personal stories" through which a person's acts and attributes become intelligible (Langenhove and Harré 1999, p.16-17). Positioning is the discursive process by which persons are located in discourse (Davies and Harré 1990). Each interlocutor may position others or be positioned by them (e.g., responsible or irresponsible, controlling or powerless, active or passive, ingroup or outgroup). In narration, positions adopted by 
characters are related to storylines. Someone may be positioned as a powerless victim in court, and an oppressor in the storyline of familial life.

A position points out personal traits. It is the total sum of obligations, rights and duties in a social milieu. It limits what a person can say or do (Harré and Moghaddam 2003). Positioning is about assigning positions, the process by which people are located in an interaction (Davies and Harré 1999). When one assumes/assigns duties and rights in conversation, he/she positions himself/herself in a certain storyline (Tan and Moghaddam 1999). Positioning refers to the discursive self-construction through words, especially personal stories (Tan and Moghaddam 1999). In this concern, positions are different from roles in being more dynamic. Negotiation of identity in a communicative act is a basically energetic process (Davies and Harré 1990).

Positions are consequences of conversations in which speakers establish "a sequence of position/act-action/storyline triads" (Davies and Harré 1990, 20). Each act evolves according to a certain storyline, which is defined as being the context of the act (Slocum and Van Langenhove 2003). Storylines are clusters of narratives resulting in the evolving of incidents and the setting of positions (Moghaddam et al. 2008). The storyline determines the positions negotiated. The position is the part played; the status negotiated in the storyline. Acts are actions performed by persons and become meaningful in a joint storyline (Harré 1997). New storylines require developing acts which, in turn, lead to new adopted positions. Consequently, the storyline is determined by positions and speech acts. In this regard the storyline, the position and the action are all interrelated in the sense that these are elements determining one's position. Langenhove and Harré $(1999,18)$ define the previous tri-relation as being the positioning triad/triangle:

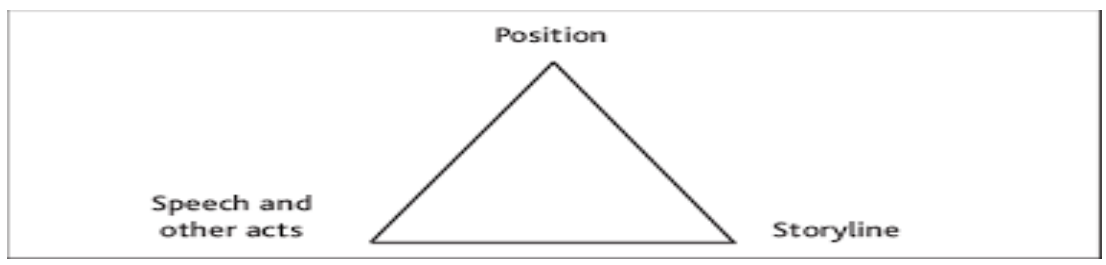

Figure 1: The Positioning Triad/Triangle (Langenhove and Harré 1999, p.18).

The notion of speech acts (Austen 1962) is pivotal in positioning analysis. Speech acts have to do with the pragmatic function of certain utterances. In pragmatics, which is about meaning in use, there is a gap between the literal 
meaning of a sentence and its communicative function. Some verbs, a case in point is "I promise", have the pragmatic functions of performing rather than stating that one is promising. Performative verbs such as "promise, request, judge, call, apologize" are called illocutionary acts. Illocutions are performing acts through utterances. Perlocutionary forces are what is achieved as a consequence of saying something.

Searle (1975) classifies illocutions into:

1-assertive: an illocution that represents a state and commits the speaker to the truth of the proposition.

2-directive: an illocution that makes the hearer do something.

3-commissive: an illocution that commits the speaker to a future action.

4-expressive: an illocution expressing the speaker's attitude or emotions concerning a state.

5-declarative: an illocution causing a certain state.

Modes of Positioning

People's words may be other -oriented, positioning the others, or selforiented, positioning the self. The former case is "interactive positioning", while the latter is "reflexive positioning" (Langenhove and Harré 1999). Langenhove and Harré (1999) add that positioning is basically distinguished between first and second order positioning.

First order positioning refers to a person's roles that are initially negotiated in conversation. For example, If A says to B "prepare food", this means that A and $\mathrm{B}$ are positioned in a way that makes A entitled to give orders to $\mathrm{B}$ who can be commanded. First order positioning is performative and tacit. It is performative in the sense that people position themselves within a progressing storyline. A person, for instance, may order another one to leave. The result may be the act of leaving. As a result, first order positioning leads to an action, a performative act. Performative positioning is the consequence of accepting whatever may be imposed by a speech act. First order positioning is tacit because people participating in conversation do not position themselves, and others, intentionally.

Second order positioning has to do with resisting first order positioning through questioning it. When a person defies first order positioning by assuming a right to refuse to behave according to it, he/she repositions himself/herself in what is called second order positioning (Langenhove and Harré 1999). This repositioning is accountive in the sense that repositioning entails "talk about talk...within an ongoing discussion" (21). It is also intentional. 
When a person positions, or repositions, himself/herself and others in a current conversation, this practice is either first or second order positioning. If a person discusses or criticizes previous interactions with whoever uninvolved in them, which is explained by Langenhove and Harré, $(1999,21)$ as being "accountive positioning outside the initial discussion", this act is third order positioning.

Moral positioning is understood within people's roles and the institutional features of a situation. When the storyline moves to consider private circumstances or individual traits, personal positioning becomes at hand.

Types of Intentional Positioning

According to Langenhove and Harré, (1999), types of intentional positioning include deliberate self-positioning, forced self-positioning, deliberate positioning of others and forced positioning of others.

\section{Deliberate Self-Positioning}

Deliberate self-positioning has to do with an interlocutor's act communicating a certain personal identity. This is achieved by indicating one's agency, referring to one's rights and potential. The first-person singular pronoun "I" is a grammatical device signifying a specific personal identity. A second strategy expressing deliberate self-positioning is the indication of personal points of view and experiences. A third strategy is to mention events and actions in an individual's biography. Narrating what one sees, experiences and does is an indicator of personal identity and deliberate positioning of the self.

It is thought that pronouns signify the way a person positions another as being an ingroup member, through the use of "we", or an outgroup member, through using "you".

\section{Forced Self-Positioning}

When a speaker has to report personal incidents because somebody else initiates a question inquiring about these incidents, the speaker is forced to position himself as a respondent. This forced positioning may be moderate, between peers, or strict, in institutional settings.

\section{Deliberate Other-Positioning}

People may deliberately position another person either in his presence, through offering him/her a location in a story, or his/her absence, through telling a gossip. 


\section{Forced Other-Positioning}

When a person is forced to describe an act and, accordingly, positions the doer of the action, this refers to forced positioning of others. This positioning may take place in the presence or the absence of the person positioned.

The following table is prepared for this research in order to summarize the different modes of positioning:

\begin{tabular}{|l|l|lr|}
\hline First order positioning & Second order positioning & \multicolumn{2}{|l|}{ Third order positioning } \\
\hline $\begin{array}{l}\text { Initial positioning of } \\
\text { self/others in talk. }\end{array}$ & $\begin{array}{l}\text { Challenging first order } \\
\text { position through refusal, } \\
\text { denial or questioning. }\end{array}$ & $\begin{array}{l}\text { Positioning outside the } \\
\text { current talk. }\end{array}$ & and \\
\hline Performative and tacit. & Accountive and intentional. & $\begin{array}{l}\text { Accountive } \\
\text { intentional. }\end{array}$ & current \\
\hline $\begin{array}{l}\text { Relative to the current } \\
\text { episode }\end{array}$ & $\begin{array}{l}\text { Relative to the current } \\
\text { episode. }\end{array}$ & $\begin{array}{l}\text { Outside the } \\
\text { episode. }\end{array}$ & \\
\hline Unintentional & $\begin{array}{l}\text { Deliberate (expressive of } \\
\text { identity through showing } \\
\text { agency, personal views, } \\
\text { experiences and using } \\
\text { pronouns. }\end{array}$ & Deliberate & \\
\hline
\end{tabular}

Table 1: Types/Modes of positioning.

\section{Methodology}

Data of this paper are the two selected stories, Nadia and her mother narrated in Darraj's The Inheritance of Exile (2007). Data are available online at (https://www3.nd.edu/ undpress/excerpts/P01156-ex.pdf). Siham is Nadia's mother. In consequence, both represent a clear image of the problems encountered by the older and the newer generations of Arab immigrant in America. Though Darraj's The Inheritance of Exile contains eight stories, the current research has a focus on two for the purpose of its size. In spite of examining two stories out of eight, these stories summarize the main sufferance Arab-American immigrants endure.

The framework of analysis is the theory of positioning proposed by Langenhove and Harré (1999) and Davies and Harré (1990). Nadia and Siham are representatives of the cultural conflict undergone due to their attempt to make peace between the two identities: their Arabic roots and their present American 
citizenship. Positioning analytical framework is applied to signify that struggle as apparent in discourse. For this reason, some extracts from Nadia and Siham's storylines are linguistically analyzed. Throughout the positioning analysis, the storyline is used to refer to the beginning of an experience that may have its impact on the character's identity. When the extract begins a new storyline, a new event or a new experience is narrated. Nadia and Siham's stories are analyzed. Each significant quote in both stories is studied in the analysis section. Numbers following each extract represent the page number of that extract in the original narrative. Storylines, positioning analysis and speech acts are considered in relation to identity construction. For each quoted part, the mode and the type of positioning are explained. The analysis section is followed by a discussion. The discussion section throws light on the major implications and the interpretations of the study. The conclusion summarizes the findings. In the end, limitations of the study and suggestion for further research are illustrated.

\section{Analysis: Negotiating Identity}

A daughter of Palestinian immigrants who has settled into the southern part of Philadelphia, Nadia is caught between her cultural heritage from the Middle East and her present in the United States. Siham, Nadia's mother, has a separate story. Both stories, Nadia and Siham's, indicate the struggle between their Arab identity and the American one. Analysis starts with Nadia because her story is narrated first in Muaddi Darraj's The Inheritance of Exile. A storyline is used to refer to a new narrative thread. Each new experience represents a new storyline. Accordingly, one story may have many storylines.

Through the story, Nadia was twenty-one. She was born in the United States to a Palestinian mother, Siham, and an American father, Nader, who was born and raised in Palestine. Nadia was brought up in a culturally-Palestinian household by parents who emigrated from Palestine to America. Accordingly, she is familiar with American customs and Arab inheritance. She is surrounded by the American culture, but consumed by Arab traditions. The coming analysis attempts to shed some light on Nadia as a female, Arab and American persona.

Nadia's first speech act is an assertive illocution stating clearly that she has Arab legacy: "Nobody believes what I said about Siti" (3). In these words, Nadia comments on other people's talks that are not present at the time of speaking. This is a personal third order positioning as she locates herself as being different from the rest of her family. She communicates her distinct personality through the subject position "I" which locates her as an active person. Her Arab identity, apparent from the word "Siti" which is the Arabic equivalent of "grandmother", 
comes first. Nadia's first speech act deliberately positions her as an Arab, active and distinct character. She positions her own self as being stubborn. This is indicated when she refuses her mother's statement that the grandmother is dead. Nadia uses a personal second-order positioning to deliberately communicate her headstrong personality in "But I saw her (Siti)" (4)

Nadia deliberately/personally positions herself as a sensitive daughter in a totally new storyline when she remembers her dead father "as he looked when he played baseball with me" (4). The previous assertive speech act reports Nadia's American habits, playing "baseball" with her father. After sharing with the readers her experience about playing baseball, Nadia narrates a new experience that marks a new storyline. She, again, deliberately positions herself as a delicate granddaughter with Arab cultural heritage in "while listening to her tapes of Om Kulthoum" (p.4). In this new storyline, Nadia reports her Arab roots as she refers to an Arab super star in singing, Om Kulthum. The previous two extracts are instances of third order positioning. Recollecting past memories, Nadia positions her own self as having both American and Arab identities. She dreams of her grandmother saying, "You have to help her, habibti" (5). In this directive speech act, a new storyline begins in which Nadia is positioned as being helpful to her mother. This is a first-order moral positioning which calls up Nadia's Arab identity in "habibti", which is the Arabic equivalent of "my love". The example presents Nadia as morally positioned according to her role as a daughter who is expected to support her mother.

Nadia creates a new storyline, a new narrative thread, when she reports "all my aunts beat their foreheads... They had flown in from Jerusalem for the funeral, arguing that their mother should be buried back home" (p.5), which is a third order personal positioning. Nadia is deliberately located amid Arab traditions. Mentioning "Jerusalem" is a clear indication of Nadia's Arab roots. This Arab identity is brought close to a statement which positions Nadia as an American citizen: "But Mama, exhausted from crying and lack of sleep, had hysterically insisted that Siti be buried here, in Philadelphia" (5). The previous two extracts are significant in the sense that they produce a new storyline in which Arab identity clashes with the American one. Nadia's aunts choose "Jerusalem", while her mother insists on "Philadelphia" as a place to bury the dead grandmother "Siti". In her act communicating her private experience, Nadia deliberately/personally positions herself as a female caught between a conflict resulting from her Palestinian legacy and her American present. So, from the very beginning Darraj seems to have a focal point. Darraj has selected discourse items which emphasize two opposing cultures. When Darraj 
intentionally mentions "Siti, habibti, Om Kulthoum, Philadelphia, Jerusalem", she makes it clear that the story is mainly about bicultural identities and the resulting inner discrepancy.

Nadia positions herself, deliberately and personally, as an Arab female when she talks about her name: "in Arabic, it meant "the dew on the flower's petal" (6). She employs third order positioning to negotiate her personal Arab identity. She asserts that her name is from Arabic origins. The same interpretation is highlighted when Nadia utilizes third order positioning to narrate her father's comment that "Only the Arabs give their kids names that are pictures" (6)

Cultural clashing identities are signified clearly when Nadia uses third order positioning to deliberately locate herself as suffering from inconsistent lives. Her assertive illocutions announce her factual struggle as she creates a storyline about her aunt:

At thirty, she had married a "non-Arab", as he became known among the family, who also referred to him simply as ... "al-Amerikani." But his real name was Kevin and he was an Irish-American,... Actually, Siti was the most suspicious... "He won't understand our culture," she'd insisted. (6)

Nadia has already, and personally, positioned her identity as an Arab, American, and a female. The aforementioned extract asserts that the Arab culture, indicated by "our culture", and the American culture are two opposite poles. Ingroup identity, denoted by "our culture", and outgroup identity are depicted as being in a quarrel. Moreover, she deliberately positions herself as a Christian when she creates a third order positioning via the storyline about her aunt's marriage in the church: "She married Kevin despite the frown that Siti wore throughout the entire church ceremony" (p.6). The previous assertive illocution reports traditions of Christian marriage. The new storyline signifies the two culturally-fighting identities. "Kevin" is a symbol of the American identity that never comes to terms with the Arab identity which is manifest in "Siti".

In America, it is natural for youth to have emotional affairs and talk about these affairs with their family and friends. This manner marks American identity. Nadia deliberately/personally positions herself as an American female through her assertions "I was newly in love...I thought about my date with George" (p.7). This stands as first-order positioning as it locates Nadia in a new storyline about her romantic entanglement. Her lover is from Syria and Nadia's mother has 
invited him for dinner "cooking his favorite dishes, like warakdawali and magloubeh" (p.7). This third order/deliberate positioning of George locates him in a storyline about his Syrian identity and his inclination towards Arab food. George positions Nadia's mother as an Arab-American when saying "Maselkhair, Sitt Jundi" (p.8). In this first order positioning, he uses the Arabic equivalent for "good evening" and "Mrs." and calls her by her husband's surname as Americans do. This is an apparent signal of George's inner confusion, a confusion that is due to his bicultural identity.

Nadia wants to go on a trip with George and a group of friends. She comments that this group trip will end "worry about a-naas" (p.11). She adds that "A-naas is a phrase that I had often heard her fret over: "What will a-naas say?" "What will a-naas think?"' (p.11). This third order positioning narrates a new storyline about the Arab's concern with social gossip. Nadia deliberately positions herself, and her family, as inheriting Arab customs even though they live in America. This is a moral positioning as Nadia is expected to act according to her Arab identity and care for gossip. The Arabic word "a-naas" is deliberately used instead of its English equivalent "people". This use of Arabic discourse amidst English discourse signifies the inner conflict George experiences.

Nadia explains what is meant by "a-nnas":

the small but organized network of Arab women and men in America who had the uncanny ability to transmit a single, juicy nugget of information about someone's reputation across the Atlantic Ocean and the Mediterranean Sea to the corresponding family network back in the Middle East. (11)

The previous extract is an assertive illocution beginning a new storyline about the Arab tradition of gossip. This is a third order/deliberate positioning of Arab groups as being fond of rumors and scandals. Nadia is morally positioned as being a victim of belonging to a chattering society, in reference to her Arab identity. This example delivers the message that Nadia positions Arab immigrants as being a source of trouble.

Muaddi Darraj presents another related short narrative. It is about Siham, Nadia's mother. Siham stands for the first generation of immigrants. In telling Siham's story, Darraj tries to mirror cultural conflicts and struggles of double identities experienced by Arab immigrants over generations. 
After Siham marries Nader, she has to travel to America where they both settle down. The start of Siham's life in America is marked by a comparison between her parents' home in Palestine and her new flat in America:

The floors of the apartment were what Nader called "hardwood"- ... She'd never seen floors like this; her parents' home had marble floors in every room. In Jerusalem, all the homes, even those of the very poor, were made of stone. (15)

Siham is deliberately, and personally, positioned, by the narrator, as being captured by two cultures: that of Jerusalem and that of America. This extract, through a third order positioning, asserts Siham's double identities. The storyline in this extract illuminates two contrastive settings between which Siham is located.

Siham is deliberately positioned, once more, as being suspended amidst the two lives. Nader buys her a present, which leads to a comparison between two worlds:

It used to cost her thirty shekels, or ten dollars, in Jerusalem's finest drug stores. Here, in America, it was only two dollars at Eckerd. The most amusing things he bought her were Barbie dolls, the most American toy of all, with their long blonde plastic hair. (16-17)

Siham is located in the middle between past experiences and present life. The previous extract employs a third order personal positioning to deliberately position Siham among past memories and present events. The storyline includes both sides of her life: the past in Jerusalem and the present in America. The assertive illocution indicates her actual battle between what was and what is.

She is deliberately/personally positioned by the narrator as being a person suffering from language differences and the resulting troubles in communication. This is indicated in the third order positioning which reports a new storyline about Siham's moral problematic position. Siham has to learn English so that she may be able to communicate with other people in her new life: "She practiced her English like a religion..." and she rehearsed her verbs for at least an hour every morning (17). The narrator deliberately positions Siham as an Arab female sticking to her Palestinian identity: "She was embroidering a small coin purse for herself, using the black and red design of the Palestinian villages" (17). This third order personal positioning is followed by another one 
which starts a new storyline locating Siham in her new American society: "Her English book lay open on the armrest and she read the sentences aloud" (17). A third order personal positioning comes next so as to emphasize Siham's fighting identities "especially practicing the words with the letters "p" and "v," which did not exist in the Arabic alphabet." (17). Each of the previous positioning examples defines a new storyline stating Siham's Arab identity, her American identity and the resulting struggle between the two cultures. Assertive illocutions make it clear that Siham is deliberately positioned as standing in the middle of two contrastive cultures.

Siham feels anxious when a lady calls and asks about "Nader". Nader, in an attempt to reassure Siham, deliberately positions her as an Arab wife when he prefers the Arabic word "Habibti" (18), which means "my love" in English, in order to relieve her. Another storyline follows and another second order positioning locates Siham as an American citizen when Nader asserts: "in America, that's what they do. These telephone people; they don't use 'Mr.' and 'Mrs.' anymore" (18). A third storyline follows in which Nader deliberately positions Siham as being entrapped in the conflict between her two contrastive identities in "You'll get used to these little cultural things" (18). Nader's use of assertive speech acts serves his point that he reports facts about Siham's cultural differences.

The narrator generates a storyline through assertive illocutions. Via these illocutions, Siham is deliberately/personally positioned as being isolated in "South Philadelphia" where "Siham felt it was an island, lonely, despite the flow of people" (18). This positioning is of a third order type because it states facts about Siham. These facts are out of an ongoing conversation and not part of the current conversation. This instance of positioning is very critical as it interprets the title of Muaddi Darraji's narrative. Siham is positioned as being exiled in Philadelphia where she inherits alienation and loneliness. Storylines become more effective when they report comparisons between Jerusalem and Philadelphia, or the past identity (Arab) and the present one (American). These storylines, expressed via assertive illocutions, position Siham in her dilemma of hesitation between past and present life. A third order personal positioning is made by the narrator to deliberately locate Siham as a confused immigrant having a past clashing with the present:

Sometimes, the Italian Market reminded her of the Old City quarter of Jerusalem... In Jerusalem, she could bargain with the peddlers. In fact, they were insulted if you did not engage them in some level of 
negotiations. But in the Italian Market, the price was set. She knew because she'd once tried to talk the fruit man down two dollars. "Hey lady, no bargaining! This is already a bargain, ahw-ight?" Even this talent was taken from her here. (p.18)

The last statement in this extract "Even this talent was taken from her here" generates a storyline in which Siham is deliberately positioned as being deprived and disadvantaged. This assertive speech act is another inheritance of Siham's exile in America.

The narrator returns to Siham's past life in Jerusalem before her marriage and her travel to Philadelphia. The new storyline recites incidents in which Siham is deliberately/personally positioned as having a purely Palestinian identity. Through third order positioning, Siham is situated "next to the entrance to the Dome of the Rock" in the "Old Country" (19). She paid "eight shekels" for a wallet while Nader who is "one of these returning American Arab nouveau riche" and "Amerkani" paid "fourteen" (19). Nader, in contrast to Siham, is being positioned at this point as having two identities. The storyline shifts to another location in Jerusalem. Again, Siham is deliberately/personally positioned as being a Palestinian-Arab citizen. Assertive illocutions position her as having an Arab identity: "... (Siham) sipping the bitter Turkish qahwa from the small, enameled cup. The boy shot in the riots yesterday had died last night. There were expansions planned for six more settlements, four in the West Bank" (19).

Siham's mother likes Nader because he complements "her cooking, the spice in her falafel, and the texture of the laban in her mansaff" (p.20). This third order positioning sets Siham's Arab identity through illocutions which assert Arab traditions in cooking. This storyline confirms Siham's past Arab identity, yet it rapidly shifts to mark a new one: "One month later, after he and his family had formally asked for her hand in marriage, Siham applied for a visa to the States. Nader had recently become a citizen himself, so she filed happily as "spouse of U.S. citizen." (20). This asserts the very beginnings of Siham's position as having newly American identity. Through a deliberate third order positioning, she is morally placed at her first journey towards having an Arab-American identity.

A new storyline recounts Siham's new position as an Arab-American wife. Events move to take place in Phildelphia, at Siham and Nader's apartment. In this new storyline located in America, Siham is deliberately/personally 
positioned as an American citizen with Arab roots and traditions. Hence, the two identities are positioned facing one another:

When they'd first moved into the apartment... Siham had insisted on first driving a small nail in the wall so that she could hang a charm above their heads. It was a blue glass stone, with an eye painted on it, a charm that hung in every home in Jerusalem. "To ward off the Evil Eye." (20)

In Philadelphia, Siham follows Arab legacy as she believes in the evils of envy. As an Arab from Jerusalem, she hangs a charm so that it may prevent "the Evil Eye" in America. This storyline, and the related third order positioning, crystallizes Siham's contradictory identities. She behaves as a purely Palestinian female though she is in "Philadelphia".

In spite of living in America, Siham is still attached to her Arab identity. A new incident reflects that conflict. A blonde woman demands to see Nader. In this storyline, Siham is deliberately positioned as a typical Arab wife: "she questioned Nader about it, as soon as he walked into the apartment" (22). This third order positioning further develops a situation in which Siham is deliberately positioned as being a tough detective as her very name refers to: "Her father used to say, as he furrowed his shaggy brows, that his daughter had been aptly named. Siham meant "arrows" in Arabic. Straight to the target. No deviations" (22). Comparisons between Jerusalem and Philadelphia are frequent contexts in which Siham is deliberately/personally positioned as a female suffering from two irreconcilable identities. The following assertive illocution is a third order positioning which determines that strife: "By October the leaves on the occasional tree in South Philadelphia began to change colors. The trees in Jerusalem were mostly olive trees and they didn't change colors" (22). Siham is, once more, deliberately positioned as being a castoff prisoner. When communicates with her sister who is "at home", Siham is located by this third order/personal positioning away from home. Her American identity is released when she mentions the American tradition of celebrating Halloween: "One autumn afternoon she slipped two leaves, a yellow one and a red one, into an envelope and mailed them to her youngest sister, Nadia, who lived at home. She also described Halloween to her" (23).

In the previous storyline/situation, Siham is positioned as being nostalgic. She is also positioned as being a lover of American traditions, expressed by her interest in "Halloween". Missing her "home" in Jerusalem and showing interest 
in American traditions, Siham is personally positioned, via assertive speech acts, as attempting to reconcile between her two realities. Her fight to adapt to American traditions is reported in her trying to resist her desire to open a letter delivered to Nader. She is, thus, deliberately positioned as being a confident American wife. This is a form of moral positioning because, as an American wife, she is expected to act reasonably without emotional reactions. This third order positioning places Siham as attached to her American identity: "she glanced at the letter, wanting to open it, but she was an American wife now and they were "cool" about these things. No suspicions. A marriage was a friendship in America, not a spy operation" (24).

Siham is preoccupied with comparing Jerusalem to America. This comparison is the subject of a new storyline in which she is deliberately positioned as being suspicious of Americans because of their modern life style: "Unlike Jerusalem, where gossip lines kept everyone updated on their neighbors, someone could hide an entire life, conceal so many secrets behind America's veil" (27). The previous part is a third order positioning notifying a major distinction between Arabs and Americans. Arab morals make them spread every piece of information. Americans, on the contrary, do not interfere in others' lives. Siham is grateful to Arab customs which leads them to detect and expose private details. In Arab traditions, couples are accustomed to hanging their wedding pictures on the wall. Siham follows that convention. In doing so, she is positioned as a typical Arab wife. This is deliberate/third order positioning. Moreover, the wedding portrait generates a storyline that pertains to Siham's Arab identity: "Siham gazed up at the portrait. She and Nader stood before the white stone wall that formed the back of her parent's house in Jerusalem. The Dome of the Rock, with its golden cupola, was visible in the background" (29). The previous third order positioning asserts Siham's Arab identity. It locates Siham next to the most significant landmark in Jerusalem, "The Dome of the Rock", though Siham was about to leave for America and be given American citizenship. In this manner, she is deliberately/personally positioned as standing amidst two cultures, two lives, two locations that are totally dissimilar.

"My name is Siham al-Jundi" (30) is Siham's first order positioning for herself. This statement locates her American identity as she gets her husband's surname, which is an American custom. This is a moral positioning because Siham is named after her husband's surname, which is an American rule of conduct. This storyline asserts Siham's American identity. Siham has a deep belief in "Evil Eyes", which is a purely Arab legacy. This heritage makes her "write to her mother, asking her to mail a few more blue stones" (32). In this 
storyline, Siham is deliberately/personally positioned as having an Arab identity, an identity that makes her consider "blue stones" to be a deterrent to envy. The analysis confirms Siham's two identities, two manners of life, two styles of living and two personalities. She is a Palestinian female wife attempting to conform to her moral role as an American citizen. She is obsessed with Jerusalem though she has already started a new life in Philadelphia. Siham is split into two identities in almost every situation as she is always preoccupied with Jerusalem although she lives in Philadelphia. She is even more split than Nadia. This is because Siham always compares and contrasts Palestine with America. Siham's divided identity makes her liken her life in America to an exile. Nadia, on the other hand, is not as psychologically-torn as Siham. She is born and raised in America, while Siham is born and raised in Jerusalem. That is why Nadia represents the second generation of immigrants who are more able to work in within the new western culture. This is apparent in Nadia's behaviors which indicate her double identity with no reference to the idea of living in an exile. Nadia does not compare every scene in America to its duplicate one from Palestine. She is not as prepossessed with Palestine as Siham. This is a normal act in the light of their different childhood circumstances.

\section{Discussion: Biculturalism and Identity Discourses}

Muaddi Darraj is an example of bicultural writers. Accordingly, two identities are expected to be discovered in her very words. It is not surprising that Darraj has a tendency to present characters having bicultural identities in her stories. She tends to narrate the cultural conflicts suffered by her characters, the conflicts that she may have undergone due to her double identity. Discourse is considered to be the lenses through which these conflicts are enacted. Discourse about identity needs an approach that explores the way people are located by themselves, and by others, as discourse proceeds. Consequently, positioning analysis, the storylines created and the speech acts uttered appear to be appropriate tools in order to detect divergent identities in narratives.

Darraj seems to emphasize biculturalism and its consequentially-complicated problems as she deliberately selects discourse components which belong to clashing cultures. From the very beginning, Nadia's storylines are composed of discourse items representing two differing cultures. This results in two fighting identities which cause uneasy life. Siham's storylines represent a deeper clash between Arab and American cultural identities. This is expected because the first generation of immigrants is thought to be slower to adapt to change. Nadia and Siham usually narrate past events. They usually narrate their memories and 
report comments which are not part of an ongoing conversation. In doing so, third order/personal positioning seems to be the dominant mode. This may go back to their sense of not being incorporated in the American society. They belong to Arab origins and their new life in America does not overpower their Arab roots. Their sense of displacement makes them escape from the present to past memories.

Assertive speech acts are almost the illouctionary force which is noted. Assertions state facts and unquestioned events. These assertive illocutions are a suitable choice because Nadia and Siham describe their life and express it throughout the story. Via their descriptions, their negotiated-double identities are asserted. Previous studies do not pay much attention to the application of PT so that clashing identities may be disclosed in short narrative discourses by bicultural writers. Approaching discourse about identity and revealing the inner struggles as being negotiated by that discourse may help in identifying the hardships which immigrants experience. As a result of having their voices and sufferings heard, immigrants may be dealt with consideration. They may be able to reconcile with their dual identities in the end.

The analysis of the texts in the previous section proves that the inner conflict passes across generations. The new generation, embodied by Nadia, has the heritage of bicultural identity. Though Nadia's discourse shows less instances of dualism, it still reveals clashing identities. Being more able to adapt to the new identity, Nadia embodies the hope that younger generations may be more successful in overcoming cultural struggles. When Siham is positioned as being in a prison, she highlights the interpretation of the title of Darraj's story. The Inheritance of Exile indicates that immigrants inherit loneliness and isolation in America which is positioned as being an exile, not the land of dreams. The assertive illocution signified by the title creates a storyline which summarizes the outcome of leaving one's homeland, the outcome that one lives in an exile. This study has employed PT, which draws from cultural psychology, as a theoretical and a methodological framework to analyze narrative discourse about bicultural immigrants. Incorporating PT, narrative discourse analysis and discourse about identity, this research is multidisciplinary. It is expected that this paper may shed more light on discourse about bicultural identities in short stories.

\section{Conclusion}

The research proves that bicultural identities can be accessed via PT. Positioning analysis uncovers Nadia and Siham's two clashing identities. Both 
are deliberately and personally positioned as being displaced between Palestine and Philadelphia, the Arab identity and the American one. Nadia and Siham's names belong to the Arab culture. The ladies carry their Arab heritage upon themselves, yet they have to cope with the American tradition. Discourse analysis proves that they are always caught between past memories and present life. This is an important finding in the understanding of bicultural identities. It helps in identifying their sufferings, a thing which may motivate the society to support them and be conscious of their problems. Biculturally-negotiated identities in short narratives symbolize real persons who suffer because they live in a place totally different from their original homeland. Persons with double identities need to be understood and accepted by whoever communicates with them. This understanding will help them to lessen their sense of confusion. That is why this paper attempts to bring to the fore immigrants' inner conflicts.

Among the challenging aspects of this study is finding relevant literature on the analysis of narrative discourse via the application of PT so that bicultural identities may be detected. Literature is thought to be addressing emotions. Data of analysis pertain to a literary short narrative. Framework of analysis pertains to PT as a tool to analyze literary discourse objectively. Detecting inner conflicts in short narratives and observing an unbiased discourse analysis may not be easy. Yet, it is thought that researching negotiated identities via an unbiased analysis may help to illustrate the fight inside, which seems to be a preliminary step to diminish it. This research finally suggests that discourse about biculturalism and the negotiated divergent identities requires more scholarly attention from researchers.

\section{Works Cited}

Austin, John. 1962. How to Do Things with Words. Oxford: Oxford University Press. The Classic Lectures on Performatives and Speech Acts.

Barkhuizen, Gary; Benson, Phil and Alice Chik .2014. Narrative Inquiry in Language Teaching and Learning Research. New York: Routledge.

Brockmeier, Jens. 2012. "Narrative Scenarios: Toward a Culturally Thick

Notion of Narrative." In Oxford Library of Psychology, edited by J. Vasliner, The Oxford Handbook of Culture and Psychology (pp. 439-467). New York, NY: Oxford University Press.

Castells, Manuel. 2001. The Power of Identity. Oxford: Blackwell.

Darraj, Susan Muaddi. 2007. The Inheritance of Exile. Stories from South Philly.

Notre Dame, Indiana: University of Notre Dame Press. 
Davies, Bronwyn, and Rom Harré. 1990. "Positioning: The Discursive Production of Selves." Journal for the Theory of Social Behaviour, 20(1), 4363.

-----, Bronwyn and Rom Harré. 1999. "Positioning and personhood." In Positioning Theory, edited by Rom Harré and Van Langenhove, (pp. 32-52). Oxford: Wiley-Blackwell.

-----, Bronwyn. 1989. "The Discursive Production of the Male/Female Dualism in School Ssettings". Oxford Review of Education, 15, 229-24.

Djité, Paulin. 2006. "Shifts in Linguistic Identities in a Global World." Language Problems \& Language Planning, 30(1).1-20.

Fairclough, Norman. 2003. Analyzing Discourse: Textual Analysis for Social Research. London: Routledge.

-----, Norman and Ruth Wodak. 1997. "Critical Discourse Analysis". In Discourse as Social Interaction, edited by T. van Dijk, Discourse Studies: A Multidisciplinary Introduction, Vol. 2, pp. 258-84. London: SAGE.

-----, Norman. 1992. Discourse and Social Change. Cambridge: Polity.

Harré, Rom and Fathali Moghaddam . 2003. "Introduction: The Self and Others in Traditional Psychology and in Positioning Theory." In The Self and Others, edited by Rom Harré and Fathali Moghaddam, (1-11). Westport, CT: Praeger.

-----, Rom. 1997. "Forward to Aristotle: The Case for a Hybrid Ontology." Journal for the Theory of Social Behaviour, 27, 173-191.

-----, Rom. 2012. "Positioning Theory: Moral Dimensions of Social-Cultural Psychology." In The Oxford handbook of culture and psychology, edited by J. Valsiner,(pp. 191-206). New York: Oxford University.

-----, Rom and Van Langenhove. 1991. "Varieties of Positioning." Journal for the Theory of Social Behaviour, 21(4), 393-407.

Huntington, Samuel. 2004. Who Are We? The Challenges to America's National Identity. New York: Simon \& Schuster.

James, Melanie. 2014. Positioning Theory and Strategic Communication. A New Approach to Public Relations Research and Practice. London \& New York: Routledge.

Kay1-Aydar, Hayriye. 2019. Positioning Theory in Applied Linguistics. Research Design and Applications. Palgrave Macmillan.

Kroskrity, Paul. V. 1999. "Identity." Journal of Linguistic Anthropology, 9(12).111- 114.

Kwihangana, Felix. 2020. Preservice Language Teachers Developing Digital Teacher Identities Through the Process of Positioning. Retrieved from 
$<$ https://www.academia.edu/43640137/Preservice_language_teachers_devel oping_digital_teacher_identities through the process_of positioning $>$.

Langenhove, Van and Rom, Harré.1999. "Introducing Positioning Theory." In Positioning theory: Moral contexts of intentional action, edited by Rom Harré and Van Langenhove, (pp. 14-31). Oxford: Blackwell.

Moghaddam, Fathali and Rom Harré. 2010. "Words, Conflicts and Political Processes."In Words of conflict, words of war: how the language we use in political processes sparks fighting, edited by F. Moghaddam and R. Harré . Praeger: Santa Barbara, CA, pp. 1-28.

-----, Fathali; Harré, Rom and Naomi. Lee .2008. Global Conflict Resolution through Positioning Analysis. New York: Springer.

Paltridge, Brian. 2006. Discourse Analysis: an Introduction. London: Continuum, Print.

Saqip, Natasha. 2020. Positioning - A Literature Review. Retrieved from $<$ https://www.emerald.com/insight/content/doi/10.1108/PRR-06-20190016/full/html>.

Scollon, Ron. 1996. "Discourse Identity, Social Identity, and Confusion in Intercultural Communication." Intercultural Communication Studies. VI: 1.

Searle, John. 1975." A Taxonomy of Illocutionary Acts." In Language, Mind, and Knowledge, edited by K. Günderson. Minneapolis, vol. 7.

Slocum, Nikki and Van Langenhove. 2003. "Integration Speak: Introducing Positioning Theory in Regional Integration Studies." In The Self and Others: Positioning Individuals and Groups in Personal, Political and Cultural Contexts, edited by Rom. Harré and Fathali. Moghaddam, (pp. 219-235). Westport, CT and London: Praeger.

Smith, Anthony. 1992. "National Identity and the Idea of European Unity." International Affairs, 68 (1), 55-76.

Tan, Siu Lan, and Fathali Moghaddam. 1999. "Positioning in Intergroup Relations." In Positioning theory, edited by Rom Harré and Van Langenhove, (pp. 178-194). Malden, MA: Blackwell.

Warming, Hanne; Galløe, Lotte R.; Carlsen, Anna Rosa and Rasmussen, Sara Romme. 2019."Beasts, Victims or Competent Agents: The Positioning of Children in Research Literature on Manipulation." Childhood, 26(1), 3953. $<$ https://doi.org/10.1177/0907568218803429>.

Wodak, Ruth. 1995. "Critical Linguistics and Critical Discourse Analysis." In Handbook of Pragmatics, edited by J. Verschueren,J.-O. Östman and J. Bloomaert, pp. 204-10. Amsterdam: Benjamins.

-----, Ruth. 1996. Disorders in Discourse. New York/London: Longman. 


\section{Appendix}

The transliteration scheme used in this paper is the Transliteration Scheme for Non-Roman Scripts, which is approved by the Library of Congress and the American Library Association.

\begin{tabular}{|c|c|}
\hline 1 & $\mathbf{A}$ \\
\hline ب ب & B \\
\hline$\Xi$ & $\mathbf{T}$ \\
\hline ث & Th \\
\hline ج & $\mathrm{J}$ (MSA)/ g (ECA) \\
\hline$\tau$ & h \\
\hline$\dot{\tau}$ & Kh \\
\hline$د$ & D \\
\hline$\dot{j}$ & Th \\
\hline J & $\mathbf{R}$ \\
\hline j & $\mathbf{Z}$ \\
\hline س & $\mathbf{S}$ \\
\hline ش & Sh \\
\hline ص & $\underline{\mathbf{s}}$ \\
\hline ض & de \\
\hline$b$ & t \\
\hline ظ & $\mathrm{z}$ \\
\hline$\varepsilon$ & 6 \\
\hline$\dot{\varepsilon}$ & Gh \\
\hline فت & $\mathbf{F}$ \\
\hline ق & $\mathbf{Q}$ \\
\hline ك & $\mathbf{K}$ \\
\hline J & $\mathbf{L}$ \\
\hline 5 & $\mathbf{M}$ \\
\hline ن & $\mathbf{N}$ \\
\hline 0 & $\mathbf{H}$ \\
\hline 9 & W \\
\hline s & $\mathbf{Y}$ \\
\hline أ & $\vec{a}$ \\
\hline$!$ & $\overline{\mathbf{I}}$ \\
\hline
\end{tabular}

